\title{
¿Cuándo el buen periodismo se convierte en activismo y cuándo el activismo deja de ser un buen periodismo? ¿La distinción sigue siendo importante para los periodistas? When does good journalism become activism and when does activism cease to be good journalism? Is the distinction still important for journalists?
}

\author{
Jorge Freddy Bolaños López ${ }^{1}$ \\ jorge.bolanos.l@gmail.com
}

Recibido: 1/12/2016, Aceptado: 1/02/ 2017

\begin{abstract}
RESUMEN
Este trabajo analiza el punto hasta el cual los conceptos de activismo y periodismo se combinan cuando se reportan temas o noticias. Considerando conceptos filosóficos y contemporáneos y aplicándolos a ejemplos de periodismo recientes, el artículo explorar los conflictos en los que se envuelven la ética, inclinación e imparcialidad al momento de escribir piezas para medios establecidos y cómo es posible para que estos se reconcilien en el ejercicio periodístico.
\end{abstract}

Palabras clave: periodismo, ética, activismo, medios, imparcialidad

\begin{abstract}
This paper analyses the point until which activism and journalism concepts combine when it comes to report news and issues. Considering philosophical concepts and contemporary definitions and applying them to recent journalistic examples, the article explores the conflicts involving ethics, bias and impartiality when writing pieces for mainstream newspapers and how possible it is for these to reconcile during the journalistic exercise.
\end{abstract}

Keywords: journalism, ethics, activism, media, impartiality

\section{Journalism}

According to the Media Entertainment and Arts Alliance "Journalists describe society to itself. They convey information, ideas and opinions. They search, disclose, record, question, entertain, comment and remember.

\footnotetext{
1 Docente Universidad Tecnológica ECOTEC. Ecuador
}

Revista científica Ciencia y Tecnología Vol 17 No 14 págs. 70-75

http://cienciaytecnologia.uteg.edu.ec 


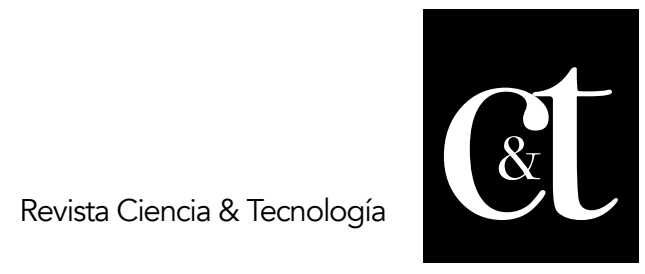

No. 14, 30 de abril de 2017

ISSN impreso: 1390 - 6321

They inform citizens and animate democracy. They give a practical form to freedom of expression. They scrutinize power, but also exercise it, and should be responsable and accountable (Tapsall \& Varley, 2001).

Journalists are the link between the news and the audience. As messengers their responsibility is to show every event in the most objective way possible and they are accountable for the interpretation of the news they deliver.

Objectivity as balance helps the journalist to set a middle ground in what they are reporting. When there are two extremes the journalist takes both and put them in way that no criticism is present in the journalistic piece (Rosen, 1993).

Aristotle view on ethics is linked to the role, which applied to the good journalism concept looks for a journalistic balance creating the mean and accomplishing happiness (Harrison, 2004). The application of the Aristotelian view can be applied here in the sense that a good journalist will deliver a news piece in a fair way showing balanced information.

The journalism of attachment proposed by Bell goes against the definition of journalism and encourages a different version in which the objectivity ceases to be a relevant aspect in order to exercise good journalism, because there is nothing objective-like in the relationship of human and event, but there is a dynamic interaction between them (Bell, 1991).

Oxford dictionary describes activism as the policy or action of using vigorous campaigning to bring about political or social change (Oxford University Press, 1884). Civil Society Organizations are important actors in activism. Their main goal is to, through activism; achieve a political goal and social change (Olesen, 2008).

In good journalism there are three essential things to consider: Accuracy: facts (events, names, dates, statistics, places, quotes) must be correct and verified by multiple sources. Fairness: all the relevant sides of the story have to be shown and balanced.

Bias: the language used has to be neutral and the journalist's personal bias has to be left out of the story (Olesen, 2008).

On the 2nd of October 2015, a shooting took place in Parramatta. Farhad Khalil Mohammad Jabar, a 15-year-old boy shot to dead a police force employee, then he was shot to dead as well by three policemen during a shooting (Raston, Beni-Morrison and Olding, 2015).

The story by the Sydney Morning Herald, mentions the place, date and names of the people involved correctly, therefore we can see that the article is accurate. The article also shows a testimony from the police force speaker and informs how they tried to contact the young boy's sister but she couldn't be reached, so it is shown the testimony of the chairman of the Parramatta Islamic association.

We can see how different sides of the story are being considered and given the proper space in the article. Also, the article narrates the story without expressing any opinions by the journalist or anyone related to the Sydney Morning Herald. This journalistic structure is common in mainstream newspapers and broadcast media. 


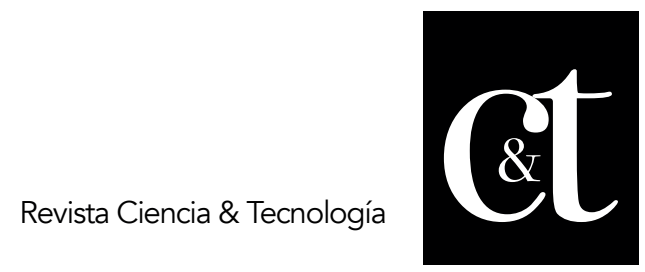

No. 14, 30 de abril de 2017

ISSN impreso: 1390 - 6321

\section{Bell's Journalism of Attachment}

Martin Bell's position on journalism of attachment comes from his history as a war journalist and bases on the inability of journalist to detach when confronted with victims and oppressors, good and evil (Holguin, 1997).

Bell's proposal goes along with Kant's views on ethics. Bell's call for actions against the evil when reporting fits with Kant's view saying that no ethic act can be done without a good will on the performer's side (Kant, 1909).

Journalism of attachment consists in having the goal to spark public debate and place an issue in the public agenda (Holguin, 2008).

In investigative journalism, there is an activist-like dimension in print and broadcast media pieces. It is called activist-like because "the documentaries were not primarily produced with an activist agenda in mind, but on the basis of professional journalistic standard" (Olesen, 2008).

In 2013, Luke Mogelson, an international freelance journalist went into a voyage as asylum seekers from Indonesia to Australia (Mogelson, 2013). His journey was narrated from the very first moment he arrived in Indonesia until he was spotted by Australian Coastguards in the open sea. The article shows photographs and narrates empathetically the struggle that the asylum seekers go through; in a detailed way it is written how problematic an asylum seekers journey is from the moment they start dealing with the smugglers and how their lives are in great danger during the trip in rustic, overloaded ships.

It is narrated how there is a shortage of water and food and how men, children and even pregnant women with no other option decide to do it knowing the odds are against them. The audience's opinions started to pop out on social media with some describing the actions as "a little dumb" and others describing them as "courageous".

But what called most the attention of the media was that Sandi Logan, the Australian department for immigration communications manager expressed his opinion about it calling it a "crazy risky" and stating that if the boat had gone down, people wouldn't have thought it was such a good story (Mogelson, 2013).

This article possesses the activist-like dimension mentioned before. It narrates a story about a topic which many NGOs advocate and without losing its journalistic professionalism it gives the chance to spark public debate and awareness.

\section{Activism vs Journalism}

Activism and journalism can be seen as two opposite terms. Journalism is based on objectivity which definition is to concentrate on matters independent of the mind, to present an external world that is either observable or verifiable, especially by scientific methods (Tapsall \& Varley, 2001) meaning that when writing a journalistic piece, there is no place for the journalist's own ideas, but for proven and verifiable facts, whereas the activism proposed by Bell encourages journalists to demand action to be taken against the oppressors in warzones (Holguin, 2008) which makes objectivity not a requirement for reporting a journalistic story.

Though, when exercising journalism, regardless the objectivity and truth of the facts, there is always going to be framing of the story. And framing will be present because 


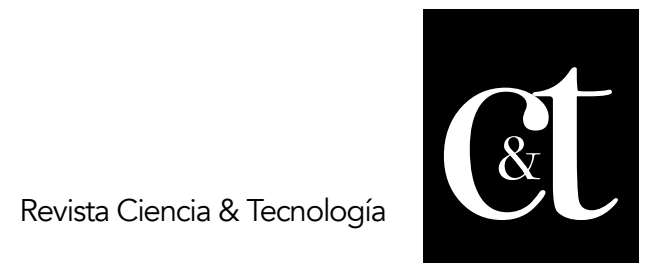

No. 14, 30 de abril de 2017

ISSN impreso: 1390 - 6321

the journalist is the one who is going to decide how to condense all the material for one story and there will be conscious decisions on why publish some things over than others (Olesen, 2008).

There is not a point where journalism and activism can fit together, however, an activist- like dimension can be considered a middle ground between the two concepts.

There are some concrete aspects that make a piece of good journalism to become an activist piece instead.

The agenda setting: From a journalist side, the agenda setting can be motivated by journalistic goals, which can be the purpose of the journalist for having a reflection of his professionalism in the piece (Olesen, 2008). On the other hand, to make a piece activist, the agenda setting must have other motivations, such as the achievement of political goals. Also, in activism the CGO's are seen as actors who are part of the issue which potentially can enhance their professional status and help them to develop (Olesen, 2008).

The nexus: journalists' job is to report in the most objective possible way, even if, how it was mentioned before, there will be framing always present. It is crucial for the journalistic piece to show all the necessary points of view in order to create a balanced and fair atmosphere.

In activism, there is a clear connection between the actor and the issue (Olesen, 2008). Blaming: Unlike framing, blaming doesn't show a balance of the different sides on the issue, on the contrary, it advocates for a specific issue and exposes its own demands in order to achieve a goal (Olesen, 2008).

In 2009, Oliver Stone, and award-winning director, made a documentary called south of the Border in which there is an analysis of the emerging South American socialist anti United States governments. In this documentary, the South American leader who is most spoken about is Hugo Chavez, former president of Venezuela (South of the Border, 2009).

The documentary portrays Hugo Chavez as the political enemy of Bush administration and with images and juxtapositions shows him as a beloved hero by Venezuelan people. It can also be noticed the use of dead people during a coupe accompanied by sad music and the narration saying that they were killed by the opposition of Hugo Chavez which later blamed him for the murders.

Throughout the documentary, it is shown how the United States were involved in the destabilization plans in Venezuela, however it doesn't show any opinions from people or organizations who belong to the opposition.

In 2014, Chris Delforce, an Australian animal rights activist released a documentary called "Lucent" which explored a closer look to the pig farming industry across the Australian territory (Aussie Farms, 2014). In the film there are very explicit images showing the precarious and cruel treatment received by the pigs in different slaughterhouses. It goes through the whole process from the moment of pregnancy to the final slaughter of a pig destined to be consumed. The film also claims that legislative regulations in Australia are not enough to stop said treatment anytime soon. By showing this documentary, Delforce is encouraging the viewer to adopt a vegan diet and to create awareness of an issue that is not common to the public audience. Most of the images shown were gathered undercover. This documentary 
fills the requirements to be an activist piece in the sense that:

1. The agenda setting is to achieve a political goal, in this case, more regulations for the pig farming industry in Australia.

2. Chris Delforce is a known figure in the animal rights activism field and his bias is explicitly leaned into it.

3. In his documentary, Chris Delforce doesn't show at any point the other side of the story, which in this case, are the pig farmers and political figures talking about their practices and how they apply actual Australian regulations to their farms. Moreover, it is not shown an attempt to contact them for the documentary, which makes sense knowing that a lot of the footage in it was taken without consent of the administration of the pig farms and slaughterhouses.

\section{Conclusion}

Considering the concepts mentioned before, activism ceases to be good journalism when it is not fair when reporting an issue. Activism and journalism goals are different and cannot coexist, however, it is possible that a journalistic piece is written in an activist- like dimension considering the unavoidable framing and the influence caused by the event in the journalist.

Probably the most important aspect for a piece to be called journalism is the objectivity, which oppositely is not necessary for activism to take place.

The distinction between journalism and activism must be important for practitioners and it is shown through their code of ethics. In 1991, Sandy Nelson, a copy editor on the Morning News Tribune in Tacoma, told her story of how she was removed from a position at a newspaper because of her activities on behalf of the rights of women, gays and lesbians (Stein, 1991). She claimed that mainstream newspapers codes of ethics are a cover so they can control the life of the reporter on and off the job. She also claimed that during the time she still had the job she never reported about the issue she was being an activist for and nor would she have.

It cannot be forgotten that mainstream newspapers have large numbers of employees and that their code of ethics cannot, for the sake of the organization, hold any exceptions in regards to their employees' actions.

The Sydney Morning Herald states, as part of their code of ethics among others, states that their staff will act with impartiality, accuracy and fairness, which as Olesen mentioned, cannot be absent when writing a journalistic piece (Sydney Morning Herald, 2015).

SMH also states as part of their code of ethics that "Herald staff shall avoid any prominent activity in partisan public causes that compromises, or appears to compromise, the journalist or the newspaper. Membership of organizations or activity that may compromise the journalist's or the paper's reputation shall be declared to their section editor.

Those responsible for coverage of news, current issues and opinion shall not be members of a political party nor stand as a candidate in an election for public office" (Sydney Morning Herald, 2015) This can be connected to impartiality aspect, which cannot be achieved if there is an interest from the journalist to report about a specific topic. 


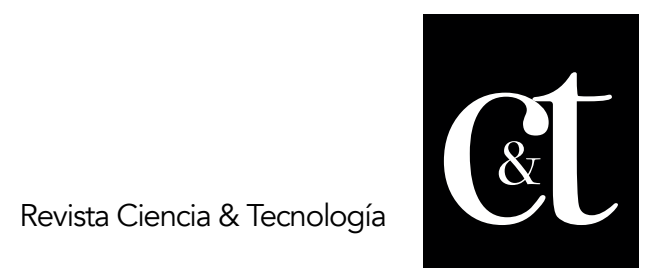

No. 14,30 de abril de 2017

ISSN impreso: 1390 - 6321

\section{Bibliographic references}

Bell, M. (1998). The Journalism of Attachment, in Kieran (ed) Media Ethics, London: Rouledge, pp 15-22.

Delforce, C. (2014). Lucent. Aussie Pigs, viewed on the 6 October 2015, http://www.aussiepigs.com/lucent.

Harrison, J. (2004). Conflicts of duty and the virtues of Aristotle in public relations ethics: Continuing the conversation commenced by Monica Walle, Prism 2.

Holguin, L. (1996). Journalism of Attachment: Virtue or Vice? Peacekeepers \& International Relations, 26 (4).

Kant, J. (1909). Critiques of Practical Reason and other Works on the Theory of Ethics. London Longmans Green \& Co., London.

Mogelson, L. (2013). The Dream Boat. The New York Times Magazine, viewed on the 6 October 2015, http://www.nytimes.com/2013/11/17/magazine/theimpossible-refugee- boat-lift-to-christmas-island.html?pagewanted=all\&_r=0.

Olesen, T. (2008). Activist journalism? Journalism Practice, 2 (2), 247-260.

Ralston N., Benny-Morrison A. \& Olding A. Parramatta Shooting: Gunman identified as Farhad Khalil Mohammad Jabar, The Sydney Morning Herald, viewed 7 October 2015, http://www.smh.com.au/nsw/parramatta-shooting-gunmanidentified-as- farhadjabar-khalil-mohammad-20151003-gk0jze.html

Rosen, J. (1993). Beyond Objectivity. Nieman Reports, vol. 4, no. 4, pp. 48-53.

Stein, M. (1991). Advocacy Journalism and Activist Lives. Editor \& Publisher, vol. 124, no. 36 , p. 16.

Stone, O. (2009). South of the Border. Viewed on the 6 October 2015, http://www. southoftheborderdoc.com/.

Tapsall, S. \& Varley, C. (2001). Journalism Theory in Practice- Oxford University Press, South Melbourne.

The Sydney Morning Herald (SMH), The Sydney Morning Herald Code of Ethics, viewed 6 October 2015, http://www.smh.com.au/ethicscode/. 